\title{
CLINICAL FEATURES OF FITZ-HUGH-CURTIS SYNDROME DIAGNOSED BY ABDOMINO-PELVIC COMPUTED TOMOGRAPHY
}

\author{
Sang Hyun Shin, MD', Young Ah Kim, MD', Doo Young Chang, MD', Kyung Chul Jun, MD', \\ Myung Kwon Jeon, MD', Kyung Ah Kim, MD² \\ Departments of ${ }^{1}$ Obstetrics and Gynecology, ${ }^{2}$ Radiology, Ilsan Paik Hospital, Inje University College of Medicine, Goyang, Korea
}

\begin{abstract}
Objective
To analyze the clinical characteristics in patients of Fitz-Hugh-Curtis syndrome diagnosed by abdomino-pelvic computed tomography (CT). Methods

We retrospectively examined the clinical courses of 62 patients who visited with abdominal pain from March 2005 to July 2010. The clinical manifestations, physical examination, laboratory manifestations, CT findings, treatments, and prognosis were analyzed.

Results

The mean age of the patients ranged from 13 to 48 years and their average age was $28.56 \pm 8.77$. Twenty-eight of them (45.2\%) were married but all the subjects had sexual experience. The chief complaints requiring a visit to the hospital were abdominal pain (74.2\%), vaginal discharge $(19.4 \%)$, nausea and vomiting $(3.2 \%)$, and fever $(1.6 \%)$. On physical examination, location of tenderness was right upper-quadrant tenderness $(41.9 \%)$, whole abdomen (37.1\%), right lower-quadrant (24.2\%), lower abdomen (16.1\%), and epigastric area (6.5\%). The isolation of bacterial pathogens was found in $26 \%$ (13/62) of them. Polymerase chain reaction tests for Chlamydia trachomatis were positive in 34 patients (70.3\%). All 62 cases showed liver capsular enhancement on CT in the early arterial phase. Peritoneal thickening (24.2\%) and fluid collection (27.4\%) were observed in the perihepatic area. Of 56 patients, 49 patients (87.5\%) improved following antibiotic therapy and conservative care. Seven patients did not respond to antibiotic therapy, their symptoms improved after laparoscopic surgery.
\end{abstract}

\section{Conclusion}

For women of reproductive age with acute pain in the upper right abdominal alone or together with pain in the lower abdomen, Fitz-Hugh-Curtis syndrome should be suggested during examination. Moreover, in cases suspected to be Fitz-Hugh-Curtis syndrome, gynecologic examination, abdomino-pelvic $\mathrm{CT}$, and tests for $C$. trachomatis could provide a more rapid and accurate diagnosis. Also, education and continuous follow up after therapy would be needed.

Keywords: Fitz-Hugh-Curtis syndrome, Abdomino-pelvic computed tomography, Chlamydia trachomatis

골반 내 염증과 동반되어 간 실질을 포함하지 않고 간 피막의 염증으 로 발생하는 간주위염을 Fitz-Hugh-Curtis 증후군이라고 한다[1,2]. 처 음 보고된 이후로 Neisseria gonorrehoeae가 유일한 원인으로 생각되 어왔다. 그러나 최근에는 Chlamydia trachomatis가 가장 흔한 원인균으 로 받아들여지고 있다[3-5]. 급성기에는 간 피막에 삼출물(effusion)과 혈관 충혈이 동반되는 염증소견을 보이다가, 만성기에는 바이올린 줄모 양의 특징적인 간 주위 유착을 보인다.

대부분의 환자들은 급성기에 갑작스러운 우상복부 통증과 압통을 호 소한다. 이러한 통증은 호흡이나 몸의 움직임으로 악화된다. 이에 Fitz-Hugh-Curtis 증후군은 담낭염, 폐렴, 신우신염과 감별진단이 어려 우며, 정확한 치료를 위해 감별진단이 매우 중요하다[6].
Received: 2010.11.1. Accepted: 2010. 12. 28. Corresponding author: Young Ah Kim, MD Department of Obstetrics and Gynecology, Ilsan Paik Hospital, Inje University College of Medicine, 2240 Daehwa-dong, Ilsanseo-gu, Goyang 411-706, Korea Tel: +82-31-910-7195 Fax: +82-31-910-7567

E-mail: camanbal@paik.ac.kr

This is an Open Access article distributed under the terms of the Creative Commons Attribution Non-Commercial License (http://creativecommons.org/licenses/by-nc/3.0/) which permits unrestricted non-commercial use, distribution, and reproduction in any medium, provided the original work is properly cited.

Copyright (c) 2011. Korean Society of Obstetrics and Gynecology 


\title{
KOREAN JOURNAL OF OBSTETRICS \& GYNECOLOGY
}

\author{
KJOG Vol. 54, No. 1, 2011
}

Fitz-Hugh-Curtis 증후군의 확진에는 급성기에 간피막 삼출물로부터 N. gonorrhoeae 및 C. trachomatis를 증명하거나 복강경 수술이나 개 복수술 같은 침습적인 시술로 확인하는 것이 필요하므로 임상에서는 보 고가 적었다. 또한 환자들의 주 호소가 급성 우상복부 통증으로 주로 소 화기 내과로 방문하고 복부-골반 전산화 단층촬영 특수 검사를 실시하 지 않아 발견이 적었던 것으로 생각된다[7].

최근 들어 복부 전산화단층촬영(computed tomography, CT)과 같은 비침습적 진단방법으로 간주위염의 특징적인 영상소견을 발견할 수 있 어 Fitz-Hugh-Curtis 증후군의 진단이 수월하여졌다. 이에 우상복부 통 증을 호소하는 여성에서 복부 전산화단층촬영으로 Fitz-Hugh-Curtis 증후군이 먼저 진단된 후에 역으로 부인과 치료를 의뢰하는 경우가 더 욱 많아지고 있다. 국내에서도 복부-골반 전산화 단층촬영으로 진단된 Fitz-Hugh-Curtis 증후군에 대한 증례보고와 임상 분석이 보고되었다 $[8,9]$. 본 저자들은 응급실과 외래의 다양한 의료 현장에서 복부-골반 전산화단층촬영으로 Fitz-Hugh-Curtis 증후군이 의심되는 환자들을 대 상으로 진단이 내려지는 과정, 임상증상, 이학적 소견, 영상소견, 치료 내용, 추적관찰과정, 예후 등을 분석하여 Fitz-Hugh-Curtis 증후군이 이 해를 돕고자 하였다.

\section{연구대상 및 방법}

\section{1. 연구대상}

2005년 3월부터 2010년 7월까지 본원에 복통으로 내원하여 Fitz-Hugh-Curtis 증후군으로 진단된 62명을 대상으로 하였다. 복부골반 전산화단층촬영에서 조영제 주입 후 간 피막 조영증강 소견이 있 을 때 Fitz-Hugh-Curtis 증후군으로 진단하였다. 간 실질, 담도, 췌장, 충수 등에 질환이 있는지 조사하고 급성복통을 일으킬 수 있는 명확한 원인이 있는 경우는 제외하였다. 부인과 진찰은 자궁경부 및 질 부위 관 찰 후 골반내진과 초음파 검사로 골반 내 감염 유무를 진단하고, $C$. trachomatis 중합효소연쇄반응 검사와 자궁경부 배양검사를 실시하 였다. 실험실 검사는 모든 환자에서 시행하였다. 복부-골반 전산화단층 촬영은 64-detector CT scanner (Aquilion 64, Toshiba Medical Systems, Tokyo, Japan)를 이용하여 $120.0 \mathrm{kVp}$ 관전압과 0.5 초의 겐트리 회전 시간으로 촬영하였다. 총 $150 \mathrm{~mL}$ 의 조영제(Ultravist 300 , Berlex Laboratories, Wayne, NJ, USA)를 초당 $3.5 \mathrm{~mL}$ 의 속도로 주입한 후 25-35초 후에 동맥기 영상을, 60-70초 후에 문맥기 영상을 얻었다.

\section{2. 연구방법}

복부-골반 전산화 단층촬영에서 Fitz-Hugh-Curtis 증후군으로 진단 된 환자들을 후향적으로 분석하였다. 환자들의 의무기록, 병력, 이학적 신체소견과 처음 진료 시의 임상소견을 조사하였다. 실험실 검사로는 혈 액의 생화학적 검사, 혈청 검사, 균 배양 검사, C. trachomatis 중합효소 연쇄반응 검사를 시행했었다. 영상 의학적 검사로는 복부-골반 전산화
단층촬영의 결과를 분석하였다. 치료 내용과 수술적 치료를 시행했는지, 예후에 대해서도 조사하였다.

\section{결 과}

\section{1. 환자들의 특징}

응급실과 외래에서 검사한 복부-골반 전산화단층촬영에서 간주위염 소견을 보인 환자는 83명이었다. 이 중 부인과 진료와 C. trachomatis 중합효소연쇄반응 검사로 Fitz-Hugh-Curtis 증후군이 진단된 경우는 62명이었다. 전산화단층촬영 후 부인과 진료를 받지 않은 9 명은 제외하 였다. 제외된 환자들의 임상적 진단은 다음과 같다. $A$ 형 급성간염 2 예, 초기 충수염 2예, 자궁내막종, 장간막 림프절염(mesenteric lymphadenitis), 전신홍반루프스, 맹단 게실염(cecal diverticulitis), 궤양성 직장염 (ulcerative proctitis), 말단 회장염(distal ileitis), 만성 활동성 대장염 (chronic active colitis)이 각각 1예씩이었다. 초기 충수염과 자궁내막종 은 수술 치료로 회복되었으며 나머지 소화기계통의 질환 환자들은 보존적 치료로 회복되었다. 환자들의 대부분은 급성복통을 호소하였기에 58 명 (93.5\%)이 응급실을 방문하였고 40 명(64.5\%)이 입원치료를 받았다. 환 자들의 연령 분포는 13 세에서 48 세로 평균 28.56 \pm 8.77 세였다. 결혼한 여성은 28명(45.2\%)이었다(Table 1).

\section{2. 임상 소견}

증상은 복통(74.2\%)이 가장 흔하였고, 질 분비물 증가 $19.4 \%)$, 오심과 구토(3.2\%), 발열(1.6\%)의 순으로 나타났다. 복부 압통의 위치는 우상복 부가 $41.9 \%$ 로 가장 많았다. 그 다음으로 전체복부(37.1\%), 우하복부 (24.2\%), 하복부(16.1\%), 심와부(6.5\%)로 나타났다. 다른 부위 압통 없 이 우상복부 단독 압통은 $22.6 \%$ 였다. 환자 중에는 심와부(6.5\%)와 좌상 부(6.5\%) 부위에 압통을 호소하는 예도 있었다. 복부-골반 전산화단층 촬영으로 Fitz-Hugh-Curtis 증후군이 진단되기 전에 임상적 증상과 초 음파소견으로 38명은 골반염(61.3\%), 9명은 난관난소농양(14.5\%)으로 진단되었다. 7 명은 다른 질환으로 의심되었다. 골반유착의심 3 명, 급성 담낭염 2명, 급성 위장염, 급성 신우신염이 각 1명씩이었다(Table 1).

\section{3. 검사 소견}

혈액 검사소견으로 백혈구(정상: 4,000-10,000/ $\mu$ L) 증가는 38.7\%에서 나타났다. Neutrophil 수(정상: 43-70\%) 증가는 53.2\%에서 나타났다. 적혈구침강속도(erythrocyte sedimentation rate; 정상: $\langle 25 \mathrm{~mm} / \mathrm{hr}$ ) 증 가는 $33.9 \%$ 에서 나타났으며 평균이 $33.97 \pm 26.09 \mathrm{~mm} / \mathrm{hr}$ 로 정상보다 높게 나타났다. C-reactive protein (정상: $\langle 0.5 \mathrm{mg} / \mathrm{dL}$ )증가는 $62.9 \%$ 에 서 나타났으며 평균이 $8.32 \pm 7.32 \mathrm{mg} / \mathrm{dL}$ 로 정상보다 증가되었다. 간 기능 검사는 aspartate aminotransferase/alanine aminotransferase (정상: 〈40 U/L)가 121/132까지 올라가는 경우도 있었으나, 60명(96.8\%) 에서 정상소견을 보였다. 배양검사는 50 예에서 시행했으며 균 동정은 


\section{KOREAN JOURNAL OF OBSTETRICS \& GYNECOLOGY}

Sang Hyun Shin, et al. Clinical features of Fitz-Hugh-Curtis syndrome

Table 1. Clinical manifestations of 62 patients with Fitz-Hugh-Curtis syndrome

\begin{tabular}{|lc|}
\hline Clinical manifestations & \\
\hline Age (yr) & $28.56 \pm 8.77$ \\
Marital status & $28(45.2)$ \\
Chief complaints & \\
Abdominal pain & $46(74.2)$ \\
Vaginal discharge & $12(19.4)$ \\
Nausea and vomiting & $2(3.2)$ \\
Fever & $1(1.6)$ \\
Location of tenderness & \\
RUQ & $26(41.9)$ \\
Whole abdomen & $23(37.1)$ \\
RLQ & $15(24.2)$ \\
Lower abdomen & $10(16.1)$ \\
Epigastric area & $4(6.5)$ \\
LLQ & $4(6.5)$ \\
First impression & \\
Pelvic inflammation disease & $38(61.3)$ \\
Tubo-ovarian abscess & $9(14.5)$ \\
Pelvic adhesion & $3(4.8)$ \\
Acute cholecystitis & $2(3.2)$ \\
Acute gastroenteritis & $1(1.6)$ \\
Acute pyelonephritis & $1(1.6)$ \\
\hline Vas are & \\
\hline
\end{tabular}

Values are presented as mean \pm standard deviation or number (\%). RUQ, right upper quadrant; RLO, right lower quadrant; LLQ, left lower quadrant.

13예(26\%)에서 보였다. 배양된 균주로는 Streptococcus agalatae 6예, Staphylococcus aureus 3예, Escherichia coli 3예, coagulase negative staphylococcus 1예였다. C. trachomatis 중합효소연쇄반응 검사는 34예에서 시행했으며 $70.6 \%$ 가 양성으로 니왔다. 균이 동정된 환자에서 C. trachomatis 중합효소연쇄반응 검사의 양성률은 $77.8 \%$ 였다(Table 2).

\section{4. 복부-골반 전산화단층촬영}

조영제 주입 후 간 피막의 조영이 증가되는 소견은 $100 \%$ 에서 보였다. 복막 비휘(peritoneal thickening) 15예(24.2\%), 체액의 축적(fluid collection) 17 예(27.4\%)에서 관찰되었다. 골반염에 상응하는 소견은 36예(58.1\%), 난관난소농양은 9 예(14.5\%) 보였다. 17예에서는 간주위염 소견으로만 Fitz-Hugh-Curtis 증후군을 의심하였다(Table 2).

\section{5. 치료 결과}

환자 62 명 중 6 명은 치료 후에 추적관찰이 되지 않아 제외하였다. 주 사제는 2 세대 cephalosporin, aminoglycoside, metronidazole을 주사
Table 2. Laboratory findings and computed tomography findings in patients with Fitz-Hugh-Curtis syndrome

\begin{tabular}{|c|c|}
\hline Variables & \\
\hline \multicolumn{2}{|l|}{ Laboratory study ( $n=62$ ) } \\
\hline WBC $(1,000 / \mu \mathrm{L})$ & $9.66 \pm 3.28$ \\
\hline Neutrophil (\%) & $73.34 \pm 11.18$ \\
\hline $\mathrm{ESR}(\mathrm{mm} / \mathrm{hr})$ & $33.97 \pm 26.09$ \\
\hline $\mathrm{CRP}(\mathrm{mg} / \mathrm{dL})$ & $8.32 \pm 7.32$ \\
\hline AST (U/L) & $21.32 \pm 25.93$ \\
\hline $\operatorname{ALT}(\mathrm{U} / \mathrm{L})$ & $15.46 \pm 26.22$ \\
\hline \multicolumn{2}{|l|}{$P C R(n=34)$} \\
\hline Chlamydia trachomatis & $24(77.8)$ \\
\hline \multicolumn{2}{|l|}{ Microbiologic culture $(n=50)$} \\
\hline Streptococcus agalatae & $6(12)$ \\
\hline Staphylococcus aureus & $3(6)$ \\
\hline Escherichia coli & $3(6)$ \\
\hline Coagulase negative staphylococcus & $1(2)$ \\
\hline \multicolumn{2}{|l|}{ Computed tomography findings $(n=62)$} \\
\hline Liver capsular enhancement & $62(100)$ \\
\hline Peritoneal thickening & $15(24.2)$ \\
\hline Fluid collection & $17(27.4)$ \\
\hline Findings compatible with PID & $36(58.1)$ \\
\hline Findings compatible with TOA & $9(14.5)$ \\
\hline \multicolumn{2}{|c|}{$\begin{array}{l}\text { Values are presented as mean } \pm \text { standard deviation (SD) or number (\%). } \\
\text { WBC, white blood cell; ESR, erythrocyte sedimentation rate; CRP, } \\
\text { C-reactive protein; AST, aspartate aminotransferase; ALT, alanine } \\
\text { aminotransferase; PCR, polymerase chain reaction; PID, pelvic } \\
\text { inflammatory disease; TOA, tubo-ovarian abscess. }\end{array}$} \\
\hline
\end{tabular}

하였고, 경구용 항생제는 3세대 cephalosporin과 doxycycline를 투여 하였다. 약물치료를 받은 56 명 중 49 명(87.5\%)에서 호전되었으며, 통증 이 완전히 없어질 때까지 기간은 평균 $7.60 \pm 6.48$ 일이 걸렸다. 항생제 주사를 평균 5.25 2.91 일 사용하였으며, 경구용 항생제는 $14.66 \pm 7.14$ 일 동안 사용하였다. 이후 재발은 3 예(6.1\%)에서 보였으며, 간격은 1주에 서 1년으로 다양하였다. 약물치료에서 호전되지 않거나 악화되는 7 명 (12.5\%)은 복강경 수술을 받았다. 전산화단층촬영에서 난관난소농양을 보인 9예에서 전원된 1명을 제외한 7예(87.5\%)가 수술적 치료를 받았 다. C. trachomatis는 중합효소연쇄반응 검사를 받은 6 예 중 5 예에서 동정되었으나, Fitz-Hugh-Curtis 증후군의 특징인 간 주위 바이올린 줄 모양 유착은 수술 중 관찰되지 않았다.

\section{고 찰}

Fitz-Hugh-Curtis 증후군의 발생률은 보고자들마다 차이를 보이며 골 


\title{
KOREAN JOURNAL OF OBSTETRICS \& GYNECOLOGY
}

\author{
KJOG Vol. 54, No. 1, 2011
}

반 내 염증성 질환을 가진 환자의 $1-20 \%$ 로 다양하게 보고되었다 [10-12]. 감염 경로로 직접적인 전파, 혹은 임파관이나 혈액을 통해서 전파된다든지 복합적인 경로로 전염된다고 생각된다[13].

Fitz-Hugh-Curtis 증후군의 병인론은 주로 N. gonorrhoeae 및 $C$. trachomatis에 의한 생식기 감염으로 골반 내 감염을 일으키고, 나팔관 을 통하여 원인균이 복강을 통해 직접적으로 이동하거나, 혈액 및 임파 액 등을 통해 간 주위까지 이동하여 간주위염을 초래함으로써 급성 우 상복부 복통을 일으킨다[6,14]. 급성기는 간 피막의 삼출성 염증 때문에 간의 전면과 인접한 복벽의 혈관 충혈과 삼출액을 동반한 염증반응이 나타나며, 만성기에는 간 피막과 복면의 전면 또는 간 피막과 횡격막 사 이에 바이올린 줄 같은 유착을 남긴다[6,14]. Fitz-Hugh-Curtis 증후군 은 대부분 여성에서 생기고 또 거의 대부분에서 골반 내 염증이 그 원인 이 되기도 하지만 드문 경우에서 충수염이나 다른 복막염의 결과로 발 생하기도 한다.

Fitz-Hugh-Curtis 증후군에서 골반 내 감염은 급성 우상복부 복통 발 생하기 전에 선행하여 발생하지만, 임상적으로 골반 내 감염의 증거 없 이 발생하는 Fitz-Hugh-Curtis 증후군이 있다. 이는 C. trachomatis감 염 자체가 증상이 경미한 경우가 많기 때문이다[6]. 본 연구에서도 복부 부위 압통 없이 우상복부 단독으로 $22.6 \%$ 보였으며 심와부와 좌상부 (6.5\%) 부위에 압통을 호소하는 예도 있었다. 이에 부인과 진찰에서 골 반염 소견 없이 우상복부 압통을 호소할 경우에도 Fitz-Hugh-Curtis 증 후군을 의심하는 것이 필요하다.

전산화 단층촬영술은 간주위염의 특징적인 소견인 간 피막 조영 증강 이 잘 나타나므로 비침습적인 방법으로 Fitz- Hugh-Curtis 증후군 진단 에 이용되고 있다. 그러나 이러한 간 피막의 조영증가 소견은 전신홍반 루푸스와 관련된 간주위염 환자에서도 보고된 바 있다[15]. 본원에서도 전산화 단층촬영술에서 간주위염 소견을 보인 전신홍반루푸스 1 예를 경 험하였다. 또한 천공성 담낭염, 천공성 간농양, 결핵성 복막염, 복막성 암종증, 방산선의 간에 대한 직접적인 노출 등에 의해서도 조영 증강 소 견이 보일 수 있다[16]. 이에 정확한 치료를 위해서 Fitz-Hugh-Curtis 증후군과 감별진단하여야 한다. C. trachomatis 항체로 최근 감염을 확 인한 연구에서 환자에게 시행한 전산화 단층촬영술에서 간주위염 소견 은 환자 19 명 중 14 명에서만 관찰되어 전산화 단층촬영술 단독으로는 Fitz-Hugh-Curtis 증후군 진단에 절대적인 방법이 될 수 없다고 주장하 였다[17]. 그러나 Woo 등의 연구에선 전산화 단층촬영술로 Fitz-HughCurtis 증후군의 95.5\%를 진단하였음을 보고하였다[18].

Fitz-Hugh-Curtis 증후군의 자기공명영상 소견은 병리적인 변화에 따라 전산화 단층촬영술과 유사한 영상소견을 보인다[19]. 간 피막의 두 꺼워지는 소견은 T1WI 영상에서 동일한 신호강도(equal intensity signal) 로 보이며 T2Wl에서 신호강도가 약간 증가(slightly high signal)되어 보 인다. 체액 축적과 포함된 간 실질은 T2W에서 정상 간 실질보다 높은 신호강도(high signal)로 보인다. 또한 바이올린 줄 같은 유착도 관찰 된다.

원인균을 동정하기 위해 질, 소변, 자궁목, 간 피막에서 얻은 검체를
이용할 수 있지만 침습적인 검사인 간 피막을 제외하면 자궁목에서 가 장 흔하게 원인균이 검출되는 것으로 알려졌다. Fitz-Hugh-Curtis 증후 군의 원인균인 C. trachomatis의 검출은 일반 배양검사로는 확인할 수 없다. C. trachomatis의 검출은 현재 중합효소연쇄반응 검사를 가장 많 이 이용되고 있으나 아직까지 검출률이 낮아 반드시 C. trachomatis항 체 검사를 동시에 실시할 것을 권유한다[20]. Choi 등[17]의 연구에서 Fitz-Hugh-Curtis 증후군 모든 환자에서 높은 항체로 최근감염을 확인 하였으나, 중합효소연쇄반응 검사에서는 환자 5 명 중 1 명에서만 $C$. trachomatis가 검출되어 양성률이 낮음을 보고하였다. 또한 Fitz-HughCurtis 증후군 이외의 환자들의 급성 우상복부 동통의 원인은 주로 담낭 염, 폐렴, 장중첩, 위장관 식도역류, 급성신우신장염 등으로 이러한 질환 들도 C. trachomatis 항체검사로 쉽게 감별되었음을 보고하였다. 양 등 의 연구에선 Fitz-Hugh-Curtis 증후군 환자에서 모두 균을 확인하였 는데, C. trachomatis 중합효소연쇄반응 검사에서 음성인 환자는 Chlamydia antigen검사에서 양성이어서 두 가지 검사를 병행하는 것이 원인균을 동정하는데 도움이 된다고 보고하였다[9]. 본 연구에서는 $C$. trachomatis 중합효소연쇄반응 검사에서 $70.6 \%$ 가 양성으로 나왔다. Woo 등[18]의 연구에서 특이 항체로 원인균을 분석한 결과 $82 \%$ 에서 C. trachomatis가 양성으로 나왔고, N. gonorrhoeae는 동정되지 않았 으며, 나머지는 다른 균이 동정되었음을 보고하였다. 그러므로 다른 균에 의한 골반염으로 Fitz-Hugh-Curtis 증후군이 생길 수 있기에 $C$. trachomatis 균이 나오지 않을 경우 다른 균에 의한 감염도 배제할 수 없다.

Fitz-Hugh-Curtis 증후군 환자들의 혈액검사 중 적혈구 침강 속도 및 $\mathrm{C}$ 반응 단백질 값은 증가하였으나, 다른 질환과의 감별에는 도움이 되지 못하였다. 최근에 C 반응 단백질이 Fitz-Hugh-Curtis 증후군의 임상적 진행과정을 반영하는 표식자(marker)로 보고되었다[21]. 본 연구에서도 적혈구 침강 속도 및 C 반응 단백질 약간의 증가를 확인하였다. FitzHugh-Curtis 증후군은 간 실질에 영향을 주지 않기 때문에 간 효소 수 치는 대부분 변화가 없다. 이렇듯 혈액검사로 Fitz-Hugh-Curtis 증후군 을 감별하는 것은 어려우나, 다른 질환을 감별하며 진단을 보조하는 역 할로 활용할 수 있겠다.

Fitz-Hugh-Curtis 증후군 치료 원칙은 원인균에 적절한 항생제를 사 용하고 항생제에 반응하지 않는 경우에는 간 주위의 유착을 제거하는 수술을 시행한다. 항생제는 일반 골반 내 감염 치료에 준하며, cefotetan, doxycycline, clindamycin, gentamicin, ofloxacin 등의 항생제를 사용 한다[6]. 이 중 doxycycline과 ciprofloxacin이 유용한 치료제로 사용되 어 왔다. 임상 증상이 호전된 후에 약 48시간 동안 주사용 항생제를 사 용하며 경구용 항생제는 2 주간 사용한다[22]. 대부분은 치료 후에 증상 이 호전된다. 본원에서도 약물치료를 받은 56 명 중 49 명(87.5\%)이 호전 되었다. 그러나 여태까지 보고와 달리 3예에서 재발됐음을 확인하였다. 본 연구는 환자 의무기록을 후향적으로 분석한 연구이기에 환자 자신이 병원을 다시 찾지 않으면 재발 여부를 확인하는데 제한이 있는 연구이 다. 이에 골반염의 특성상 재발의 가능성은 더 높을 것으로 생각된다. 그 


\section{KOREAN JOURNAL OF OBSTETRICS \& GYNECOLOGY}

Sang Hyun Shin, et al. Clinical features of Fitz-Hugh-Curtis syndrome

러므로 치료 후에 재발방지를 위한 환자 교육과 꾸준한 추적관찰이 필 요하다. 치료 후 전산화 단층촬영술에서 보이는 간주위염 소견도 사라진 다. 본원에서도 2 예에서 1 주와 1 달 후에 다시 검사한 전산화 단층촬영 술에서 간주위염 소견이 사라진 것을 확인하였다.

본 연구는 복부-골반 전산화단층촬영으로 Fitz-Hugh-Curtis 증후군 이 의심되는 환자들이 진단이 내려지는 과정, 이학적 소견, 영상소견, 치 료 내용, 예후 등을 확인하였다. 이에 임상적으로 가임기 여성이 우상복 부 혹은 우상복부와 하복부 부위 통증을 호소할 경우 Fitz-Hugh-Curtis 증후군을 의심하는 것이 중요하다. 이어 부인과적으로 골반 내 감염 유 무를 확인하면서 $C$. trachomatis 균 검사와 복부 전산화 단층촬영술을 실시하여 종합적으로 판단하는 것이 Fitz-Hugh-Curtis 증후군을 신속 하고 정확하게 진단하는 길로 생각된다. 또한 치료 후에 재발방지를 위 한 환자 교육과 꾸준한 추적관찰이 필요할 것으로 생각된다.

\section{References}

1. Curtis $\mathrm{AH}$. A cause of adhesions in the right upper quadrant. JAMA 1930;94:1221-2.

2. Fitz-Hugh TJ. Acute gonococcic peritonitis of the right upper quadrant in women. JAMA 1934;102:2094-6.

3. Muller-Schoop JW, Wang SP, Munzinger J, Schlapfer HU, Knoblauch M, Tammann RW. Chlamydia trachomatis as possible cause of peritonitis and perihepatitis in young women. Br Med J 1978;1:1022-4.

4. Wang SP, Eschenbach DA, Holmes KK, Wager G, Grayston JT. Chlamydia trachomatis infection in Fitz-Hugh-Curtis syndrome. Am J Obstet Gynecol 1980;138:1034-8.

5. Wolner-Hanssen P, Svensson L, Westrom L, Mardh PA. Isolation of Chlamydia trachomatis from the liver capsule in Fitz-Hugh-Curtis syndrome. N Engl J Med 1982;306:113.

6. Peter NG, Clark LR, Jaeger JR. Fitz-Hugh-Curtis syndrome: a diagnosis to consider in women with right upper quadrant pain. Cleve Clin J Med 2004;71:233-9.

7. Lee SC, Nah BG, Kim HS, Choi TH, Lee SH, Lee JY, et al. Two cases of Fitz-Hugh-Curtis syndrome in acute phase. Korean J Gastroenterol 2005;45:137-42.

8. Ji EY, Kwon YI, Kim MJ, Kim SY, Chung JE, Kim MR, et al. A case of Fitz-Hugh-Curtis syndrome diagnosed by pelvic CT imaging prior to diagnostic laparoscopy. Korean J Obstet Gynecol 2005;48:2005-9.

9. Yang HW, Jung SH, Han HY, Kim A, Lee YJ, Cha SW, et al.
Clinical feature of Fitz-Hugh-Curtis syndrome: analysis of 25 cases. Korean J Hepatol 2008;14:178-84.

10. Eschenbach DA, Holmes KK. Acute pelvic inflammatory disease: current concepts of pathogenesis, etiology, and management. Clin Obstet Gynecol 1975;18:35-56.

11. Onsrud M. Perihepatitis in pelvic inflammatory disease: association with intrauterine contraception. Acta Obstet Gynecol Scand 1980;59:69-71.

12. Risser WL, Risser JM, Benjamins LJ, Feldmann JM. Incidence of Fitz-Hugh-Curtis syndrome in adolescents who have pelvic inflammatory disease. J Pediatr Adolesc Gynecol 2007;20:179-80.

13. Paavonen J, Saikku P, von Knorring J, Aho K, Wang SP. Association of infection with Chlamydia trachomatis with Fitz-Hugh-Curtis syndrome. J Infect Dis 1981;144:176.

14. Kobayashi Y, Takeuchi H, Kitade M, Kikuchi I, Sato Y, Kinoshita K. Pathological study of Fitz-Hugh-Curtis syndrome evaluated from fallopian tube damage. J Obstet Gynaecol Res 2006;32: 280-5.

15. Schoenwaelder M, Stuckey SL. Perihepatitis associated with systemic lupus erythematosus: computed tomography findings. Australas Radiol 2005;49:179-81.

16. Kim S, Kim TU, Lee JW, Lee $T H$, Lee $S H$, Jeon TY, et al. The perihepatic space: comprehensive anatomy and $\mathrm{CT}$ features of pathologic conditions. Radiographics 2007;27:129-43.

17. Choi TY, Kang JO, Chung SR, Ahn Y. Chlamydia trachomatis antibody in Fitz-Hugh-Curtis syndrome. Korean J Lab Med 2008;28:293-8.

18. Woo SY, Kim Jl, Cheung DY, Cho SH, Park SH, Han JY, et al. Clinical outcome of Fitz-Hugh-Curtis syndrome mimicking acute biliary disease. World J Gastroenterol 2008;14:6975-80.

19. Wang CL, Guo XJ, Yuan ZD, Shi Q, Hu XH, Fang L. Radiologic diagnosis of Fitz-Hugh-Curtis syndrome. Chin Med J (Engl) 2009; 122:741-4.

20. Ossewaarde JM, Rieffe M, Rozenberg-Arska M, Ossenkoppele PM, Nawrocki RP, van Loon AM. Development and clinical evaluation of a polymerase chain reaction test for detection of Chlamydia trachomatis. J Clin Microbiol 1992;30:2122-8.

21. Lim SC, Park YW, Choi HJ, Kim YH. Clinical experiences of Fitz-Hugh-Curtis syndrome. Korean J Obstet Gynecol 2006;49: 1738-44.

22. McCormack WM. Pelvic inflammatory disease. N Engl J Med 1994;330:115-9. 
= 국문초록 $=$

\section{복부-골반 전산화 단충찰영으로 진단된 Fitz-Hugh-Curtis 중후군의 임상양상}

${ }^{1}$ 인제대학교 의과대학 일산백병원 산부인과, ${ }^{2}$ 영상의학과

신상현 ${ }^{1}$, 김영아 ${ }^{1}$, 장두영 ${ }^{1}$, 전경철 ${ }^{1}$, 전명권 ${ }^{1}$, 김경아 ${ }^{2}$

목적

복부-골반 전산화단층촬영으로 Fitz-Hugh-Curtis 증후군이 진단된 환자의 임상양상을 분석하고자 하였다.

\section{연구방법}

2005년 3월부터 2010년 7월까지 본원에 복통으로 내원하여 Fitz-Hugh-Curtis 증후군으로 진단된 62명을 대상으로 하였다. Fitz-Hugh-Curtis 증후군 진단이 내려지는 과정, 이학적 소견, 영상소견, 치료 내용, 예후 등을 분석하였다.

\section{결과}

환자들의 연령 분포는 13 세에서 48 세로 평균 $28.56 \pm 8.77$ 세였다. 결혼한 여성은 28 명(45.2\%)이었다. 증상은 복통(74.2\%)이 가장 흔하였 고, 질 분비물 증가(19.4\%), 오심과 구토(3.2\%), 발열(1.6\%) 순으로 나타났다. 복부 압통의 위치는 우상복부가 $41.9 \%$ 로 가장 많았다. 그 다음으로 전체복부(37.1\%), 우하복부(24.2\%), 하복부(16.1\%), 심와부(6.5\%)로 나타났다. 배양검사는 50예에서 시행했으며 균 동정은 13 예 (26\%)에서 보였다. Chlamydia trachomatis 중합효소연쇄반응 검사는 34예에서 시행했으며 $70.6 \%$ 가 양성으로 나왔다. 조영제 주입 후 간 피막의 조영이 증가되는 소견은 $100 \%$ 에서 보였다. 복막 비후 15 예(24.2\%), 체액 축적 17 예(27.4\%)에서 관찰되었다. 약물치료를 받은 56 명 중 49 명(87.5\%)에서 호전되었으며, 통증이 완전히 없어질 때까지 기간은 평균 $7.60 \pm 6.48$ 일이 걸렸다. 항생제 주사를 평균 $5.25 \pm 2.91$ 일 사용하였으며, 경구용 항생제는 $14.66 \pm 7.14$ 일 동안 사용하였다. 약물치료에서 호전되지 않거나 악화되는 7 명(12.5\%)은 복강경 수술을 받았다.

\section{결론}

임상적으로 가임기 여성이 우상복부 혹은 우상복부와 하복부 부위 통증을 호소할 경우 Fitz-Hugh-Curtis 증후군을 의심하는 것이 중요하 다. 이어 부인과적으로 골반 내 감염 유무를 확인하면서 C. trachomatis균 검사와 복부 전산화 단층촬영술을 실시하여 종합적으로 판단하 는 것이 Fitz-Hugh-Curtis 증후군을 신속하고 정확하게 진단하는 길로 생각된다. 또한 치료 후에 재발방지를 위한 환자 교육과 꾸준한 추적관찰이 필요하다.

중심단어: Fitz-Hugh-Curtis 증후군, 복부-골반 전산화단층촬영, Chlamydia trachomatis 